\title{
Internal audit quality dimensions and organizational performance in Nigerian federal universities: the role of top management support
}

\author{
Suleiman Mohammed Bello \\ Ayoib Che Ahmad \\ Nor Zalina Mohamad Yusof \\ Tunku Puteri Intan Safinaz School of Accountancy \\ Universiti Utara Malaysia, Malaysia
}

\section{Keywords}

Internal audit dimensions, top management support, organizational performance, Nigerian federal universities.

\begin{abstract}
The study examines the moderating effects of top management support in the relationship between internal quality dimensions and organizational performance in Nigerian federal universities. The study employed a sample of internal audit staff at senior level from 40 federally owned universities in Nigeria where 400 samples have been drawn for the analysis. Questionnaire instrument was used in generating the data having subjected to Exploratory Factor Analysis (EFA) and Confirmatory Factor Analysis (CFA) aimed at establishing underlying dimensions. The data was collected and analysed using inferential statistics and the findings revealed that interaction of internal audit competence, internal audit independence, and internal audit size, with top management support significantly and positively influence organization performance of Nigerian federal universities. The findings provide ground for new policy initiatives to strengthen internal audit and enriched the literature by providing the moderating effect of top management support as instrumental to organizational performance. It is therefore recommended that internal audit competence internal audit independence and internal audit size should be given more attention and mechanism through which these qualities can be employed and sustained for more internal audit service delivery and efficiency in Nigerian federal universities.
\end{abstract}

Corresponding author: Suleiman Mohammed Bello

Email address for corresponding author: sbellorano@gmail.com

First submission received: $26^{\text {th }}$ October 2017

Revised submission received: $14^{\text {th }}$ February 2018

Accepted: $8^{\text {th }}$ March 2018

\section{Introduction}

Efficiency and effectiveness regarding the use of public funds being expanded to education especially higher educational institution is receiving adequate attention. Authorities are aware that high quality financial and non-financial management of its resources will lead to the success of its programme and activities (Okechuku \& Kida, 2011).To enhance this credibility, agencies have been established with the task and responsibilities as an internal control mechanism to look into the financial and non-financial operations in order to realize the value for the money expanded on various governmental programmes and activities.

This brought about the existence of Internal Audit (IA) department in institutions to assist in reviewing organizational processes and control procedures that can provide measurable assurance that public funds are being utilized in a most efficient and effective manner (Achua \& Ogunjoboun, 2014). To support government programmes and activities, the regulatory agencies such as National Universities Commission (NUC), Federal Ministry of Education and Office of the Accountant General of the Federation (AGF) and other professional groups such as Institute of Internal Auditors (IIA), International Standard for the Professional Practice of Internal Audit (ISPPIA), Statement of Auditing Standard (SAS), Institute of Chartered Accountants of Nigeria (ICAN), Association of National Accountants of Nigeria (ANAN), and many other professional groups establishes standards, codes and ethics to enhance internal audit towards the realization of organizational performance.

www.jbrmr.com A Journal of the Academy of Business and Retail Management (ABRM) 
The public sector managers require to pay more attention to the improvement of public organizations (Okechuku \& Kida, (2011). Today, government in Nigeria controls the largest business transactions which by the nature of its expenditure through its ministries and agencies improve significantly to financial and non-financial activities (Enofe, Mgbame \& Ethiorobo, 2013). Therefore, the need to have a quality internal audit function towards the realization of organizational objectives cannot be over emphasized, especially in a situation where public sectors managers find themselves operating at a complex and challenging environment due to the current economic crises (Unegbu \& Kida, 2011).

The present study is timely and very essential during the period of economic recession. In addition, knowledge about the Nigeria federal universities performance efficiency will guide the managers of those institutions to recognize the financial and non-financial short-comings, while the federal government on the other hand being the sole funder can use the research in managing its scarce resources effectively through its policy formulation and review of the existing rule and regulations (Inua \& Maduabum, 2014).

The need to focus on the performance of Nigerian federal universities is equally timely as they are among the major users of the nation's resources. This seeks to determine the extent to which internal audit quality would contribute to the performance of Nigeria federal universities via top management support. The top management of Nigerian federal universities consist of the Vice-Chancellor, who is the chief executive officer of the institution, the two deputies for Vice-Chancellor, who assists the Vice-Chancellor for academic and administrative functions, the Registrar, the university Librarian and the Bursar as the chief financial officer of the institution. Other functional organs of the university consist among others, the Deans, Directors and head of departments.

\section{Literature Review}

\subsection{Organizational Performance}

Organizational performance is considered to be among the critical factors and very useful variable in Management and accounting research (Richard, et al, 2008). It has become an indicator of wellbeing of organization (Gavrea, et al, 2011). The concept of organizational performance is used commonly among researches and academic literature; however, its definition is often difficult because of many meanings (Gavrea, et al, 2011). Organizational performance comprises the actual output or result of an organizational operation as measured against the intended output of the organization. Kaplan and Norton (1996), considered the variables of financial perspective, stakeholder's perspective, internal processes and learning and growth as the determinant factors for measuring organizational performance. What matters most for organizational stakeholders is the performance of their organization.

Universities being public organizations are expected to increase the quality of their services, efficiency and effectiveness in the utilization of their resources. Federal universities in Nigeria experience a lot of changes and reforms for effective management and reaching the stakeholders expectations. The increasing call for accountability and transference call for internal control mechanisms, government wanted university's resources to be properly safe guarded and be utilized efficiently, effectively and economically. Therefore, both the government and the university managers need to do more on internal control and performance measure for effective utilization of the scares recourses.

Early literatures (Amstrong, 2000) posited that organizational performances are based on the clear understanding of organizational mission and vision and the strategic goals. They further explained that effectiveness, efficiency and economy are the basic three parameters that are used to measure organizational performance). In addition, Kaplan and Norton (1996) provided additional definition which is commonly use in literature as, performance is an indicator of reliable information on financial and nonfinancial operations. Buregeya (2007) argued that organizational performance is the ability for organization to be efficient in producing output that meets the users and stakeholders' expectations. In other words, it is the process of which organization utilizes its scares resource efficiently, effectively and economically to produce output that are consistent with organization mission and vision.

March and Sutton (1997) earlier contended that organizations are instrument of purpose. They were regarded as coordinated activities through intentions and goals. Therefore, pointing at the purpose of organizations and evaluating comparative organizational achievements or failure in fulfilling those purposes is quite conspicuous. Part of conventional discourse from this statement, it can be deduced that 
private firms are normally measured their performance in terms of profit, and return on investment (ROI), while public organizations like Universities, performance are compared using research productivity, academic programmes, student intake, ranking by popular agency or by a university regulating body. For example, the Nigerian federal universities are being assessed and ranked by the National Universities Commission and other profession groups.

Successful organization represent key ingredient for national development. They have to be assessed and managed effectively because they are the ingredient for developing economy especially under the current economic crises. Knowing the determinants such as internal audit quality and utilizing them for the effectiveness of an organization is very crucial. Internal auditors have a great role to play and contribute towards an organization through its understanding and knowledge of the organizational risk elements and control processes (Buregeya, 2007). Management realizes that an organization achieved its desired objectives or goals when there is effectiveness, efficiency and relevant to the mission and vision of the organization were realized.

Internal audit quality perfects and complete its functions and add value based on an understanding of how contemporary organizations function. The roles of internal audit is not only to detects insufficient processes and procedures but also to suggest way to improve organizational practices in order to help the organizations to achieved the desired objectives especially in risk management (Achua \& Ogunjoboun, 2014).

Several attempts were made to evaluate or measure the performance of Nigerian federal universities using different models such as performance efficiency measure, data envelopment techniques and balance score cards (Abdukareem \& Oyeniran, 2011). The fact that this study is on the Nigerian federal universities, it is important to review the impact of internal audit quality in Nigerian federal universities and also to review some existing literature in order to determine the level of its contribution to the performance of those Universities.

\subsection{Internal Audit Quality (IAQ)}

Research on IAQ has received considerable attention in literature (Chen et al, 2005). In this paper, IAQ is characterized by IA competence, IA independence and IA size, referred in this paper as IAQ dimensions. IA is a function of highly experienced, knowledgeable and expertise staff; reasonable size of audit staff; independence and objectivity that represent the IAQ which significantly influenced organizational performance (Enofe et al, 2013).

The Statement of Auditing Standard (SAS 65) explained IAQ characteristics as involved competence that is educational level, certification and experience; objectivity which comprises elements such as sincere reporting and effective communication and quality of work performance involving adequacy of audit programme. In another development the Institute of Internal Auditors (IIA) 2002 standards 1210 as cited by Hutchinson and Zain, (2009) internal auditor's proficiency indicated that internal auditors acquire the necessary, knowledge and the competency elements required to conduct audit to ensure effectiveness. In this paper, element of IAQ such as internal audit competency, internal audit independence and internal audit size are to be considered.

IAQ has significant role in maintaining and contributing to organizational performance under the attribute of an independent IA, IA competence and adequate size of IA (Zaire, 2014). External auditors perform effectively with high quality IA which can improve and promote appropriate accounting and auditing standards by ensuring that the financial information is true and fair and can serve the organization effectively, thus giving the organization a sense of confidence (Zaire 2014).

The Public Company Accounting Oversight Board (PCAOB), stated that many factors contribute or directly influence the internal audit quality. Among the prominent ones are the IA competency which consists of experience, knowledge, skills and proficiency of internal auditor; and the rigor of the audit methodology developed under "the Audit Quality Framework" (PCAOB, 2013).

The insincerity in financial reporting raises serious concern not only in USA, Italy and New Zealand but also in Nigeria where the world over witnessed the celebrated collapse of giant companies such as WorldCom, Enron (USA), Parmalat (Italy), Nationwide finance (New Zealand), Cadbury, Afribank plc, Intercontinental Bank plc (Nigeria), (Demakis, 2011; Norwani et al, 2011; Lianne, 2011). Countries around the world have set out code of best practice as guideline to address such mischievous act, like Sarbanes 
Oxley Act (SOX) in USA, Cadbury report in Nigeria, Dev report in Canada, Kings Report in South Africa and many others with aim of improving the corporate governance (Bhagat \& Bolton, 2009).

Upon all the intervention by regulatory agencies, the challenges for determining credible financial and non - financial reporting in both private and public sectors are still prevalent. These and many other factors necessitate having in depth research on elements affecting internal audit quality considering its importance and relevance in organizational performance (Demakis, 2011). This effort is not only limited to private organization but certainly in public sectors where the prime motive is non - profit but generally directed to social services. Therefore, this paper intends to determine the relationship of IAQ and organizational performance under the dimension of IA competencies, independence of IA and IA size in order to find out the extent to which they contribute to wellbeing of organization. Having discussed on IAQ, the paper will now consider organizational performance as the main focus of the study.

\subsection{Top Management Support}

Top management support has for quite a long time been considered as a determinant factor for a successful IAQ. Management attitude towards the activities of IA has significant influence on organizational performance (Alzeban \& Gwilliams, 2014). Several studies (Cohen \& Sayag, 2010; Mahzan \& Hassan, 2015) indicated that management support is linked to provision of efficient resources to IA in the area of staff training, recruitment and professional development to improve on their competency auditor and having an independent IA department. In this study, top management support is employed as moderating variable between the independent variable of internal audit quality with the dimensions of IA competency, independence and size; and the dependent variable of organizational performance.

The idea of employing top management support to serve as moderating variable in this study is supported by Baron and Kenny (1986) which emphasized that a moderator strengthens the relationship between the predicting variable and criterion variable. Sekaran (2003) further, states that moderating variable performs the function of independent variable by strengthen other independent variables towards achieving the dependent variable. Moderating variable therefore, affects the connection between the predicting variables and the criterion variable. Sekaran (2003) also, re-affirmed that a moderator has necessarily have significant effect on the independent - dependent variable relationship and its presence modifies the original relationship between the predicting and criterion variables. Among the studies that employed a moderating variable in the area of internal audit quality, consist of Endayah and Hanefah (2013); Christopher (2014); Baharud-din et al. (2014).

Management support is one of the most crucial factors for ensuring effectiveness of IA which in turn impacted positively to overall organizational performance. Cohen and Sayag (2010) indicated that the effect of management support is in consistent with private or public organization effectiveness in their exploratory studies. The study further stated that even those determinants of IAQ such as competency, independence, size of internal audit is derived from the support of top management, given independence of IA, career development, hiring qualified and experienced staff and allocating of enough resources to internal audit department are all the result of decision made by top management.

In a related study, Christopher (2014) who employed agency theory, some relevant literature and best audit practice guidelines developed a framework which was used to determine if IA is structured to enhance good governance in Australian public universities sector, indicated that many of public universities in Australian internal audit function were carried out under dynamic structure and operational arrangement to realized good governance. Among the dimension the study examined include organization member's support which shows a significant significance relationship between organizational members support to internal auditors, the university Council, management and external stakeholders; and overall performance of the University especially in area of functional reporting relationship, staff development, internal audit independence and resourcing internal audit department.

Baharud-din et al. (2014) stated that top management contributes to the variation of internal audit quality and is obviously very significant in influencing organizational performance, because any negative change in the factors that affects those elements will give a significant negative change in the IAQ. This shows that the variable of IAQ such as competency, independence, size and quality of work performed by IA may not be strong enough to have any significant influence to the overall effectiveness of IAQ which in turn contributes to the overall efficiency of organizational performance without top management support. 
Badara and Saidin (2013) in their conceptual study on internal IA effectiveness in public organizations, suggests for further research to validate their study by employing a moderating or mediating variable in order to strengthen the relationship between the two constructs.

The idea of employing top management support was also supported by the study conducted by Endayah and Hanefah (2013) on proposition to develop the theoretical frame on IA effectiveness where they argued that IAQ is directly impacted by organizational members support. The result of their study indicated that organizational member support which was employed as moderating variable is significantly related with IAQ.

This paper demonstrates that employing a moderating variable of top management support between the independent variable of IAQ and dependent variable of organizational performance in Nigerian federal universities will result to positive impact to organizational performance. Other similar studies with similar opinion are among others Badara and Saidin (2014) and Alzeban and Gwilliams (2014) further indicated that the factors of IA independence, competency, size only, cannot guarantee IAQ, therefore, the application top management support as moderating variable in this paper will be relevant in realizing effective organizational performance.

The paper will now examine top management support as moderating variable on those dimensions of IAQ with organizational performance from the existing literature.

\subsection{IA Competency and Organizational Performance}

IA competency apparently consists the development of specialized expertise that improve the IAQ. It comprises IA experience, skills, knowledge and professional proficiency (Mahzan \& Hassan, 2015). IA competency represents one of the most essential elements in determining IAQ which improve the auditors' role towards organizational performance. The IIA, as prominent standards setters of IA highlight the importance of having essential knowledge, skills, experience and professional qualification by internal auditors to operate more effectively (ISPPIA).

Previous studies indicated on the need to conduct studies in internal auditing and its contribution to public sector organization (Alzeban \& Gwillian, 2014; Vijayakumar \& Nagaraja, 2012; Radu, 2012; Badara \& Saidin, 2013). The Institute of Internal Auditors (IIA) practice advisory 1210 - 1 state that IA should possess required knowledge, qualification, experience and other competencies for them to perform effectively. There is certainly a need to have and apply new ideas, approaches and techniques in order to improve and add value to organization (Buregeya, 2007).

\subsection{IA Independence and Organizational Performance}

IA independence is one of the most critical factors for achieving IAQ dimensions. It is seen as a key driver of the IAF (Alzeban \& Gwilliams, 2014). According to Institute of Internal Auditors (IIA) Practice Advisory Board is an instrument that allows IA department to function and conduct its responsibilities without interference.

The internal auditor's ability to exercise their responsibilities with a certain degree of independence is very critical to the profession and this challenge is typically the requirement by the corporate governance codes which indicated that IA should channel their report functionally to the audit committee (AC) of the board or council and administratively to the chief executive officer (CEO) (Ahmad and Tylor, 2009). This unique role of assurance services to organization and consultancy services to top management placed IA in a conflict situation (Stewart \& Subramaniam, 2010). The effect of IA independence an organizational performance has a wide range of literature (Mohammad, 2012; Yasin \& Nelson, 2012; Cristopher, 2014; Alwala \& Biroari, 2015).

\subsection{IA Size and Organizational Performance}

IA size is another important element in achieving internal audit quality which in turns stimulates the organizational performance. International Standards for the Professional Practice of Internal Auditors (ISPPIA) indicated IA to function more effectively it has to be sufficiently resourced (ISPPIA - Practice Advisory-2003).

Several studies suggest that the quality of IA works successfully and reliable when there is sufficient number of audit members. Alzeban and Gwilliams (2014) in their study on factors affecting the internal audit effectiveness: A survey of the Saudi Arabia public sector show a significant relationship 
between IA size and IAQ. Faruk and Hassan, (2014) found that the size of IAQ is positively related with financial performance of quoted cement companies in Nigeria, after applying multiple regression analysis. Miettinen (2011); Anderson (2012) and Bouaziz (2012) examined this relationship between IA size and firm performance and found a significant correlation.

\subsection{Top Management Support and IA Competency}

Top management support represents a key factor for the success of almost all programmes and process within organizations including internal audit. Management acceptance of and support for IAF is considered as a critical success factor to IAQ (Cohen and Sayag, 2010).

For efficient and effective internal auditing, there should be a strong management support which will ensure internal auditors possess appropriate skills, knowledge and experience (Al-Zeban and Gwilliams (2014). The level of training, education and experience as well as the level of professional qualification influences the IAQ (Al-Twaijry et al, 2004). These attributes are accorded with the support of top management for maintaining appropriate responsibilities and service delivery capabilities. A competent internal auditor could be an asset for ensuring public confidence in the entire organization (Omar and Abu Bakar, 2012; Radu, 2012; and Badara and Swaidin, 2013).

Several studies were conducted to examine the relationship of top management support and IA effectiveness (Ussahawaritchakit and Intakhan, 2011). On the study conducted by Alzeban and Sawan, (2013) on the role of IA function in the public sector context in Saudi Arabia, stated that management support for IA departments, can secure efficient staff and provide them with training and development to meet the required competency needed by the organization. And the findings of the study indicated a positive and significant relationship with top management support and IA competency. This indicates that management support is highly needed for achieving internal audit quality which complements organizational performance.

\subsection{Top Management Support and IA Independence}

The evolving and expanding role of internal auditing in organizations represent a key organizational governance mechanism and consulting services. This unique role of risk management and consultancy services to management has placed internal auditor in a conflict situation which their ability to exercise true independent and objectivity raised a lot of questions (Christopher, 2014). In addition, IA is also expected to assist management to achieve accountability and integrity and to improve on the implementation of organizational operations. It is also expected to develop confidence among the stakeholder. To achieve these fundamental attributes, IA must be independent from all decisions factors involved in the organization (Christopher, 2014). Internal audit should be allowed to exercise its responsibility without management interference.

"Internal audit independence is the freedom from condition that threaten the ability of the internal audit activity to carry out internal audit responsibility in an unbiased manner. To achieve the degree of independence necessary to efficiently carry out responsibility of the internal audit activity, the chief audit executive has direct and unrestricted access to senior management and the board. This can be achieved through dual - reporting relationship" (IIA, 2012).

Under this scenario, this study attempts to examine the moderating effect of top management support with IA independence for organizational performance. Previous studies were conducted to examine this relationship (Alzeban and Gwilliams, 2014; Alzeban and Sawan, 2013; Badara and Saidin, 2013; and Baharud-din et al, 2014). In the study conducted by Alzeban and Gwilliams, (2014) indicated that top management support is very vital determinant of IAQ and has a great and positive impact to IA independence.

Independence is very essential for any professional who provides professional services and professional judgement. Without independent of mind and appearance, the IA loses its value and credibility and their opinion becomes meaningless (Endayah and Hanefah, 2013). This suggest that from support top management to IA function provides signal of the role and value of internal auditing in the organization. Managerial support empowers IA department to discharge its responsibilities efficiently (Alzeban \& Gwilliams, 2014).

In the recent study conducted by Baharud-din et al. (2014) on the factors that contribute to the effectiveness of IA in public sector, after employing cross-sectional survey to analyze the variables of IA 
competency, IA independence and management support shows a positive and significant relationship. They indicate that successful IA department generally depends on management support strength. Management style and organizational structure determine the independent IA which provides the assurance services and consultations to the organization for effective and efficient utilization of organizational resources (Baharud-din et al, (2014). Thus, management set out the overall policy setting that enable IA to gain authority and independence in the organization and at the same time gain auditees' acceptability (Mihret, 2010).

\subsection{Top Management Support and IA Size}

As the size of organizations differs in their vision and mission, equally the IA size varies. Therefore, comparing the IA size with one and another in an organization in determining IAQ can be misleading (IIARF, 2004). In another perspective, top management consider variety of factors in determining the size of IA department in their organization on whether the investment, example, resourcing the department yield positive result? There is no doubt IA function need to be properly equipped with enough human and material resources to enable it carry out the required responsibilities for organizational effectiveness (Alzeban \& Gwilliams, 2014).

Previous studies suggest that IAQ is likely to be higher where there is enough number of IA staff (Arenne and Azzone, 2009; Ahmad et al, 2009; and Obeid, 2010). For instance, the study conducted by Ali et al. (2007) on internal audit in the State and Local Government of Malaysia indicated that major problems hindering effective internal audit performance is the severe shortage of internal audit staff. Ahmad et al. (2009) shows that limited number of IA staff is among the reasons for ineffective performance in Malaysian public sector. The study further found that with the support from top management, both staffing and resource allocation would be improved. The two studies above could have improved on their finds by employing a variable of top management support.

Arena and Azzone (2009) stated that the primary condition for IAQ to enable it to fulfil its responsibilities is to acquire enough and well-equipped professional audit staff. Alice and Rusjan (2011) supported the study by indicating that sufficient number of IA employee participation is a stronger indicator of organizational objectives. Alzeban and Gwilliams (2014) states that management support empowers IA department through the provision of sufficient resources to enable it carry out its duties efficiently. And with management support, IA department can secure available staff and have access to training and development (Alzeban and Sawan, 2013).

Alzeban and Gwilliams (2014) further, indicated that top management support has significance influence on internal audit size, from the survey they conducted on 203 internal auditors in Saudi Arabia public sector organizations. IA required to acquire the right number of qualified members of staff. This can only be achieved by support of top management (Cohen and Sayag, 2010). Al-Twaijry (2003) indicated that management support to internal audit in terms of resourcing and budgetary allocation is so significant in determining IAQ. Management support for IA is so vital for ensuring that IA have resources needed to meet their responsibilities (Christopher, 2014). Ejoh and Ejom (2014) revealed that the activities and other operation in the colleges they analyzed were initiated by top management. Therefore, management have great influence on IA activities. However, the quality of IA is not effective. The study found that IA department is not sufficiently resourced in terms of staff and does not perform their duty independently. Overall finding revealed that IA in the institutions they analyzed has no significance contribution. Under this situation, top management intervention is very critical.

Top management support has for quite a long time been considered as a determinant factor for a successful IAQ dimension. Management attitude towards the activities of IA has significant influence on organizational performance (Alzeban \& Gwilliams, 2014). Several studies (Alzeban \& Sawan, 2013; Mahzan \& Hassan, 2015) indicated that management support is linked to provision of efficient resources to IA in the area of staff training, recruitment and professional development to improve on their competency auditor and having an independent IA department. 


\section{Conceptual Framework}

Independent Variables (IV)

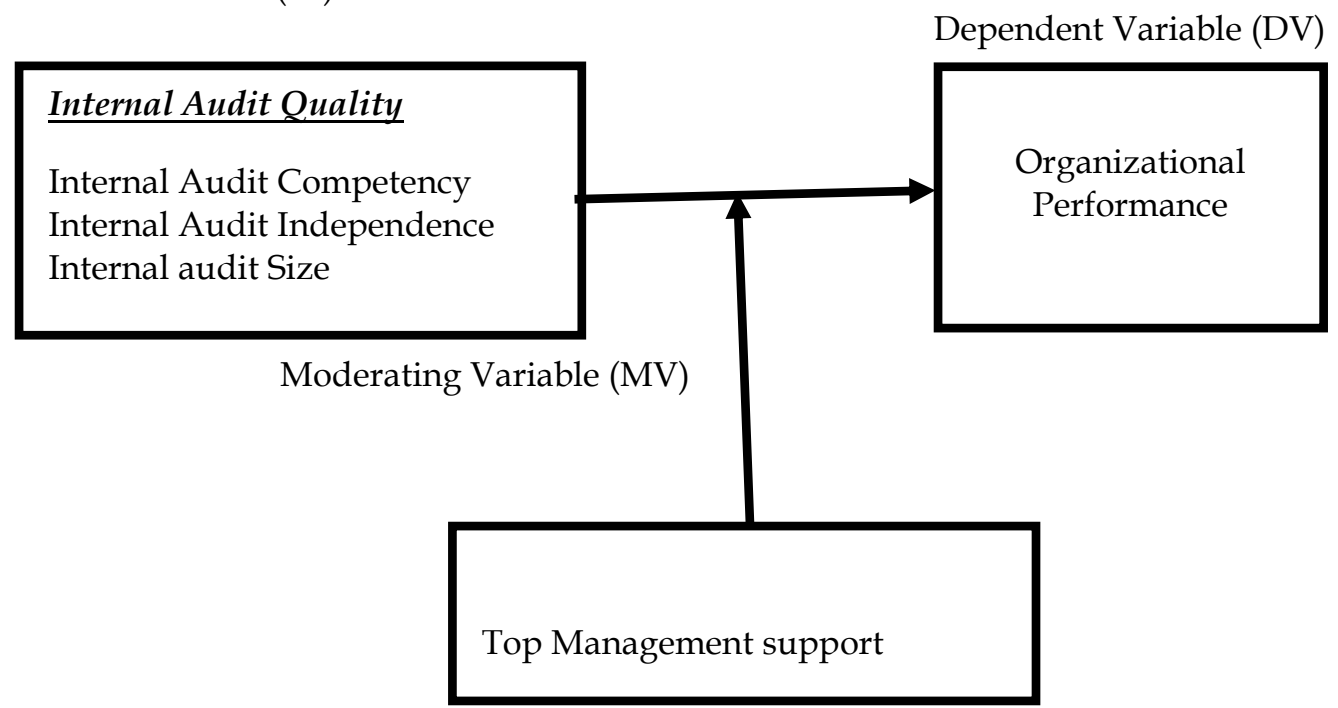

A conceptual research framework showing the relationship between independent variable, dependent variable and moderating variable

\section{Underpinning theory}

Stewardship theory is a framework which argues that people are intrinsically motivated to work for others or for organization to accomplish the task and responsibilities which they have been entrusted. It argues that people are collective minded and pro-organization rather than individualistic and therefore works towards the attainment of organizational, group or social goals because doing so gives them high level of satisfactions. Stewardship theory therefore provides one framework for characterizing the motivational behaviour in various types of organizations. It considers that from the beginning, organization serve a wider social purpose than ordinary profit making or maximizing the fortunes of shareholders. It holds that organizations are social entities that are concern with welfare of stakeholders having relationship with the organization and are affected by the achievement or performance of that organization (Donaldson \& Preston, 1995). The choice of this theory in this study is based on its prominence in public organizations, as this study focuses on public institutions, (Nigerian Federal Universities). It serves as an alternative to agency theory and offers opposing predictions about the structuring effective board. Its model is based on as "stewards" rather than what is call self-interested "agency". Although, agency theory can equally be useful in this study by showing the existence of internal audit in organization, however, stewardship theory is much appropriate and would be considered in this study.

\section{Hypotheses Development}

Base on the framework, the paper seeks to examine relationship between IAQ with dimensions of internal audit competency, independence, size and organizational performance. Therefore, seven hypotheses were formulated comprising of the followings:

$\mathrm{H}_{1}$ : There is significant relationship between IA competency and organizational performance.

$\mathrm{H}_{2}$ : There is significant relationship between IA independence and organizational performance.

$\mathrm{H}_{3}$ : There is significant relationship between IA size and organizational performance.

$\mathrm{H}_{4}$ : There is significant relationship between Top management support and organizational performance.

$\mathrm{H}_{5}$ : Top management support moderates the relationship between IA competency and organizational performance.

$\mathrm{H}_{6:}$ Top management support moderates the relationship between IA independence and organizational performance. 
$\mathrm{H}_{7}$ : Top management support moderates the relationship between IA size and organizational performance.

\section{Methodology \\ 3.1 Research Design}

In this study, the descriptive design is to be considered in order to describe the features of the designated variable in a given circumstance (Sekaran \& Bongie, 2010). In this regard, the study will focus on the IAQ as the predicting variable and organizational performance as the criterion variable, the survey method will be more suitable to achieve the desired goal. Therefore, the research setting is going to be cross - sectional, which involved collecting data at one time to be able to meet the requirement of the study's objectives (Cavana, Dalahaye \& Sekaran, 2001).

\subsection{Population and sample size}

The entire group of people, or things that researchers found interesting to study is what is termed population (Sekaran and Bougie, 2010). In this paper, IA staff at senior level in the Audit department of Nigerian federal universities constitutes the population for this study because federal universities in Nigeria are unique in their services and operations. They have common funding, constitution and laws establishing them, likewise their policy, structure and functions. The National Universities Commission (NUC), as Nigerian universities regulatory and supervising agency, stated that there are forty (40) federal universities across Nigeria (NUC, Official bulletin, 2017).

The Nigerian federal universities were considered on the ground that Creswell, (2003) describe population as a group of individual or organizations who have the same characteristics and other common features that the researcher can identify and study. Therefore, the population used in this satisfied the requirement. The whole population of forty (40) Nigerian federal universities were considered as the population of the study in order to have comprehensive and much wider responses. Further to this, the scope of the study can be appropriately managed in the data collection process using personal contact and electronic medium.

A sample is a set of participants derived from group or individual of whole population for the purpose of conducting a survey (Shehu, 2014). That is, it is subset of the population for the research process. It represents part of the entire population of interest to be studied (Shehu, 2014). It can further be referred to as a sub - collection that is picked from the population of interest. Therefore, sampling is the process through which group of representative elements or individual are selected from a given population (Shehu, 2014).

\subsection{Sample Technique}

Purposive sampling was employed in the data collection process since audit personnel that occupy senior position and have satisfactory level of experience in audit functions were considered in the sample. In each of the forty 40 federal universities ten (10) most senior internal auditors with salary scale ranges from consolidated salary structure of 07-15 were selected from each of the university as respondents. This makes a total of four hundred (400) respondents.

\section{Measures}

The study adopts measures from previous studies. The instrument has passed through ideal process of validation. The items of the instrument were generated from various sources and it has been subjected to Exploratory Factor Analysis (EFA) in order to establish the underlying factors and reduce the number of items. Construct validity and Confirmatory Factor Analysis was carried out in order to ascertain the underlying factors.

The final version of the instrument ended up with 23 items that cut across the five factors. The factors loadings, communalities, rotated component matrix have all exceeded the cut-off point of .5. The variance explained is above .70, indicating that the instrument has satisfactory validity indicators. The internal consistency of the instrument is adequate with .95 alpha coefficient, while individual constructs has .70 for competence, .70 for independence, .81 for size, .74 for management support and .84 for organizational performance 
The researcher collects data through distribution of questionnaire to respondents (Directors, Chief Internal auditors, Assistant Chief Internal Auditors, Principal Internal Auditors and Senior Internal Auditors) from the Nigerian federal universities. In order to have the completed questionnaires return within shortest possible time, hand delivery and electronic mail system were used as they suite the peculiarity of Nigerian university System.

Hand delivery and use of electronic media are considered most appropriate in order to avoid long time consumption (Sekaran \& Bougie, 2010). Research assistants were employed to assist in questionnaires distribution and follow - up through physical contacts. Telephone and e-mail were employed to fast track the collection processes from the selected sample. One of the advantages of this method other than the quick response is that the researcher gives additional explanation on items that needs clarification by the respondent.

\section{Result and Discussions}

\subsection{Result}

\subsubsection{Multiple Regression and Hypotheses Testing}

Multiple regression analysis was employed to test the research hypotheses. The analysis intends to examine the relationship between the predicting variables and the criterion variable. Hair et al, (2010), asserted that for the conduct of regression analysis, large number of samples is required and considered appropriate, and that the underlying assumptions of multiple regression analysis were fulfilled. The assumption includes among others, normality, linearity, multicollinearity, homoscedasticity which are normally investigated through the scatter plots and the normality probability plot in the regression standardized residuals.

The assumptions were thoroughly examined, and the result indicated that none of the assumption was violated in the study, therefore, making the conduct of multiple regression analysis possible.

\subsubsection{Direct Relationship}

Table 5.1.2 showing the result for direct relationship

Regression Results for Direct Relationship

\begin{tabular}{|c|c|c|c|c|c|c|}
\hline & \multicolumn{2}{|c|}{$\begin{array}{l}\text { Unstandardized } \\
\text { Coefficients }\end{array}$} & $\begin{array}{l}\text { Standardized } \\
\text { Coefficients }\end{array}$ & \multirow[t]{2}{*}{ t-stat } & \multicolumn{2}{|c|}{ p-value } \\
\hline & Coefficient & $\begin{array}{l}\text { Std. } \\
\text { Error }\end{array}$ & Beta & & & \\
\hline Constant & 1.729 & 0.150 & & 11.549 & 0.00 & \\
\hline IA Comp. & 0.065 & 0.030 & 0.096 & 2.159 & $0.03^{*}$ & Supported \\
\hline IA Independ. & 0.055 & 0.046 & 0.070 & 1.203 & 0.23 & Not Supported \\
\hline $\begin{array}{l}\text { IA Size } \\
\text { Top Mgt }\end{array}$ & 0.075 & 0.052 & 0.089 & 1.047 & 0.19 & Not Supported \\
\hline Support & 0.319 & 0.043 & 0.461 & 7.388 & $0.00^{* *}$ & Supported \\
\hline $\mathrm{R}^{2}$ & 0.496 & Adj.R² & .487 & & & \\
\hline Prob. & 0.000 & & & & & \\
\hline F-Stats & 50.29 & & & & & \\
\hline Obs & 313 & & & & & \\
\hline
\end{tabular}

* indicates statistical significance at $1 \%$

* *indicates statistical significance at $5 \%$

Dependent Variable: Organizational Performance.

H1: There is significant relationship between Internal Audit competency and organizational performance.

The result for the relationship between internal audit competence and organizational performance is significant at $(\beta=0.096, \mathrm{t}=2.159, \mathrm{p}=0.03)$, hence the hypothesis which states that there is significant relationship between IA competence and organizational performance is supported.

H2: There is significant relationship between IA independence and organizational performance. 
The result for the relationship between IA independence and organizational performance is significant at $(\beta=0.070, t=1.203, p=0.23)$, hence the hypothesis which states that there is significant relationship between IA independence and organizational performance is not supported.

H3: There is significant relationship between IA size and organizational performance.

The result for the relationship between IA size and organizational performance is not significant at $(\beta=$ $0.089, t=1.047, p=0.19)$, hence the hypothesis which states that there is significant relationship between IA size and organizational performance is not supported.

H4: There is significant relationship between top management support and organizational performance.

The result for the relationship between top management support and organizational performance is significant at $(\beta=0.461, t=7.388, p=0.00)$, hence the hypothesis which states that there is significant relationship between top management support and organizational performance is supported.

\subsubsection{Moderating Effects}

Top management support moderates the relationship between IA competency, IA independence, IA and size and the organizational performance. The moderating variable is expected to strengthen the relationship between the predicting variables and the criterion variable for maximum effectiveness (Baron \& Kenny, 1986) as shown below

Table 5.1.3 showing regression result of moderating relationship

Regression Results for the Moderating Relationship

\begin{tabular}{|c|c|c|c|c|c|c|}
\hline & \multicolumn{2}{|c|}{ Unstandardized Coefficients } & \multirow{2}{*}{$\begin{array}{l}\text { Standardized } \\
\text { Coefficients } \\
\text { Beta }\end{array}$} & \multirow[t]{2}{*}{ t-stat } & \multirow[t]{2}{*}{$\mathrm{p}$-value } & \\
\hline & Coefficient & Std. Error & & & & \\
\hline Constant & 1.077 & 0.524 & & 2.056 & 0.04 & \\
\hline IA Compet. & 0.538 & 0.158 & 0.792 & 3.397 & $0.00^{* *}$ & Supported \\
\hline IA ndepend. & 0.420 & 0.141 & 0.531 & 2.972 & $0.02^{*}$ & Supported \\
\hline $\begin{array}{l}\text { IA Size } \\
\text { Top } \quad \text { Mgt. }\end{array}$ & -0.091 & 0.149 & -0.161 & -0.609 & 0.54 & Not Supported \\
\hline Support & 0.512 & 0.172 & 0.739 & 2.971 & $0.00^{* *}$ & Supported \\
\hline IAC*TMS & 0.152 & 0.047 & 1.246 & 3.231 & $0.00^{* *}$ & Supported \\
\hline IAI*TMS & 0.156 & 0.042 & 1.310 & 3.670 & $0.00^{* *}$ & Supported \\
\hline IAS*TMS & 0.552 & 0.401 & 0.554 & 2.296 & $0.023^{*}$ & Supported \\
\hline $\mathrm{R}^{2}$ & 0.55 & Adj. $R^{2} .54$ & & & & \\
\hline Prob. & 0.000 & & & & & \\
\hline F-Stats & 33.73 & & & & & \\
\hline Obs. & 313 & & & & & \\
\hline
\end{tabular}

* indicates statistical significance at $1 \%$

* *indicates statistical significance at $5 \%$

Dependent Variable: Organizational Performance.

H5: Top management support moderates the relationship between IA competence and organizational performance

The result for regression analysis indicates that interaction of IA competence and top management support has significantly makes impact on organizational performance $(\beta=1.246, t=3.231$, $p=0.00)$, hence the hypothesis which states that there is significant relationship between interaction of IA competence and top management support and organizational performance is supported.

H6: Top management support moderates the relationship between IA independence and organizational performance

The result for regression analysis indicates that interaction of IA independence and top management support is positively and significantly makes impact on organizational performance $(\beta=$ $1.310, \mathrm{t}=3.670, \mathrm{p}=.000)$, hence the hypothesis which states that there is significant relationship between interaction of top management support and independence and organizational performance is supported.

H7: $\quad$ Top management support moderates the relationship between IA size and organizational performance 
The result for regression analysis indicates that interaction of IA size and top management support is positively and significantly makes impact on organizational performance $(\beta=0.554, t=2.296, p$ $=0.023$ ), hence the hypothesis which states that there is significant relationship between interaction of IA size and top management support and organizational performance is supported.

6.0

\section{Discussions}

Top management support appears to be an important moderator in the relationship between internal audit factors comprising of competence, size; independence and organizational performance in the federally owned universities in Nigeria. The moderating effect of top management support appears to be important indicator towards a tremendous increase in the level of efficiency and effectiveness for the performance of Nigerian federal universities.

The findings of the study revealed that interaction of IA independence and top management support was found to have the most important followed by interaction of IA competence. The importance of IAQ factors demonstrated their growing relevance and demand for IAQ service in all organisations whether public or private. The findings of the study illustrate the importance of top management support in the performance of federal universities in Nigeria. The regression analysis shows a very strong effect of internal audit competence, independence and size on organisational performance.

The significance of top management support's intervention in this study justifies the extent to which top management support remains a crucial factor in the attainment of IA objectives and performance of federal universities in Nigeria. The findings indicate that the influence of top management support is strong and consistent regardless of whether the organisation is private, or public taken into consideration of the findings of this study. Cohen and Sayag (2010),

The finding is also consistent with Albrecht and Travaglione (2003) who discovered that management support was important factor to the success of internal audit function in organizations. The findings of the study also reveal that support of management is almost crucial to the operation and success of IA departments in Nigerian universities. Top management support remains important determinant of organisational effectiveness which is derive from the support of top management by providing adequate manpower requirement to meet the required size, promote independence as well as enhancing competences of staff through training and retraining of audit staff. All these achieved through decisions of top management.

The result of the regression analysis for IA competency is consistence with previous studies (Alzeban \& Gwilliams, 2014; Cohen \& Sayag, 2010; Alzeban \& Sawan, 2013; Mihret \& Yismaw, 2007; Mahzan \& Hassan, 2015) which indicated that management support is linked to provision of efficient resources to IA in the area of staff training, recruitment and professional development to improve on their competency and having an independent IA department.

The independence of IA remains crucial in providing a better result to the organizations. This paper established that independence of IA department affects the performance of Nigerian universities to a certain extent. The finding indicates that an internal audit department must be independent in terms of personnel and operational activities of an organization. The initial result for regression analysis for testing the direct relationship between IA independence and organizational performance indicated insignificant relationship with organizational performance. However, with the interaction of moderating variable of top management support, the result indicated significant and positive relationship with organizational performance. This shows the effect of top management support in improving the effectiveness and efficiency of an organization. Therefore, top management support remains a precondition for the attainment of mandate and effectiveness of Nigerian federal universities.

The result in the interaction between IA size and top management support indicated a positive and significant relationship with involvement of top management of the institution. Therefore, the study is in conformity with the findings of Kiabel (2012), Faruk and Hassan (2014) and Christopher (2014). Like in the recent study conducted by George et al, (2015) shows that top management is associated with the IA size and IAQ is significantly related with organizational performance. The result for regression analysis for testing the direct relationship between IA size and organizational performance indicated insignificant relationship with organizational performance. However, with the interaction of moderating variable of top management support, the result indicated significant and positive relationship with organizational 
performance. This shows the effect of top management support in improving the effectiveness and efficiency of an organization. Therefore, top management support remains a precondition for the attainment of mandate and effectiveness of Nigerian federal universities.

\section{Conclusions and Recommendations \\ 7.1 Conclusion}

The study identified the interaction of the IAQ dimensions and top management support in influencing organisational performance. Theoretically, the paper has succeeded in making the theory of Stewardship theory as universal and relevant to all organisations irrespective of ownership and nature. Equally, the paper has contributed by providing additional literature involving the relationship between IAQ and organisational performance to the existing body of knowledge

The findings of the study demonstrate the IAQ dimensions influence the performance of the Nigerian federal universities. It is therefore recommended that the significant IAQ dimensions comprising IA competence, IA independence and IA size should be given more attention and mechanism through which these qualities can be sustained and be employed for more IA service efficiency and delivery in Nigerian federal universities. Further to these, university top management should always encourage IA competence by promoting knowledge and skills of the audit personnel through in-service training, workshops and seminars and ensure their independence.

Considering the outcome of the direct relation of IA competence, independence and size and moderating effects of top management support in the relationships with IA competence, independence and size and organizational performance, it is concluded that the Nigerian federal universities would have effective and reliable IA department capable of helping the universities to achieve high level of performance if given the necessary support that they required by top management.

Limitation of the study is that, even though there are several controlled variables under this model that can measure the organizational performance, yet this study only measured the dimensions of IA competency, IA independence, IA size, IA reporting line and timeliness of IA report. Apart from the demography of the respondents, other control variables which the study failed to measure consist of IA objectivity, communication, motivation, audit committee, quality of work performed by internal auditors and many others. This is since bringing all of them under the model of the study would be cumbersome. Some of them were discussed by other researches. Moreover, result from few variables is often more realistic and can easily be analyse and interpret.

\subsection{Recommendation}

Based on the finding of the study, it is recommended that IAQ dimensions consisting of IA competence, independence and size should be given more attention and mechanism through which these qualities can be sustained and be employed for more IA service efficiency and delivery in Nigerian federal universities by the top management of Nigerian federal universities.

The regulatory agencies of Nigerian federal universities, such as National Universities Commission, federal ministry of education, office of the Accountant General of the federation and office of the Auditor General for the federation should consider the review of IA policy issues regarding IA independence for efficiency and effectiveness in Nigerian federal universities. In this study, quantitative research design was employed. Future research can employ qualitative or mixed design. For instance, qualitative interview should be carried out, where the respondents may give a better understanding or response on the relationship between the constructs of the study.

\section{References}

Abdulkareem, A. Y., \& Oyeniran, S. (2011). Managing the performance of Nigerian universities for sustainable development using data envelopment analysis. International Journal of Academic Research in Business and Social Sciences, 1, 1-.12

Achua, J. K., \& Ogunjoboun, F. I. (2014). Imperative of value-for-money internal Auditing in Nigerian universities. The Nigerian Accountant, 47(1)

Ali, M., \& Rusjan, B. (2011). Material relevance of internal audit: Business benefit of using ISO 9000 international as a managerial tool. Total Quality Management Journal.23(3).

Al-Twaijry, A. A., Brierley, J. A., \& Gwilliam, D. R. (2003). The development of internal audit in Saudi Arabia: An institutional theory perspective. Critical Perspectives on Accounting, 14(5), 507-531.

www.jbrmr.com A Journal of the Academy of Business and Retail Management (ABRM) 
Alzeban, A., \& Gwilliams, D. (2014). Factors affecting the internal audit effectiveness: A survey of the Saudi public sector. Journal of International Accounting, Auditing and Taxation, 23(2), 74-86.

Alzeban, A., \& Sawan, N. (2013). The role of internal audit function public sector in Saudi Arabia public sector. African Journal of Business Management, 7(6), 443-454.

Albrecht, S \& Travaglione, A. (2003). Trust in Public sector senior management. International Journal of Human Resource Management, 14 (1).

Badara, M. A. S., \& Saidin, S. Z. (2013). The relationship between audit experience and internal audit effectiveness in the public sector organizations. International Journal of Academic Research in Accounting, Finance and Management Sciences, 3(3), 329-339.

Baharuddin, Z., Shokiyah, A., \& Ibrahim, M. S. (2014). Factors that contribute to the effectiveness of internal audit in public sector. International Proceedings of Economics Development and Research, 70, 126.

Baron, R. M., \& Kenny, D.A. (1986). The moderator- mediator variable distinction in social psychological research: conceptual, strategic and statistical consideration. Journal of Personality and Social Psychology, 51, 1173-1182. Doi: 10.1037/0022-3514.51.6.1173.

Christopher, J. (2014). Internal audit Does it enhance governance in the Australian public university sector? Educational Management Administration E Leadership, 43(6), 954-971.

Creswell, J. W. (2003). Research design.2nd edition, London, Thousand Oaks, CA.

Demaki, G. O. (2011). Proliferation of codes of corporate governance in Nigeria and economic development. Business and Management Review,1(6), 1-7.

Ejoh, N. O \& Ejom, P. E. (2014). Effects of Internal Audit functions on the financial performance of Tertiary institution in Nigeria. International Journal of Economic, Commerce and Management, 2(2).

Endaya, K. E., \& Hanefah, M. M. (2013). Internal audit effectiveness: An approach proposition to develop the theoretical framework. Research Journal of Finance and Accounting, 4(10), 92-102.

Enofe, A. O., Mgbame, C. J., Osa-Erhabor, V. E., \& Ehiorobo, A. J. (2013). The Role of Internal Audit in Effective Management in Public Sector. Management, 4(6).

FareedMastan, P., Gameda, H., Rajeswari, P., \& Muhammed, S. (2015). The Effectiveness of Internal Audit in Improving Organizational Performance: Case Study of Wollo University, Ethiopia, 2015. Indian Journal of Applied Research, 5(7).

Farouk, M. A., \& Hassan, S. U. (2014).Impact of audit quality and financial performance of quoted cement firms in Nigeria. International Journal of Accounting and Taxation, 2(2), 01-22.

Gavrea, C., Ilies, L., \& Stegerean, R. (2011). Determinants of organizational performance: The case of Romania. Management \& Marketing, 6(2), 285.

George, D., Karagiogos, T \& Konstantinos, A. (2015). Factors associated with internal audit effectiveness: Evidence from Greece. Journal of Accounting and Taxation, 7(7), 113-122.

Hair, J. F., Andersen, R. E., \& Tatham, R. L. (2010). Multivariate data analysis (7thed.). Upper Saddle River, NJ: Pearson Prentice Hall.

Institute of Internal Auditors (2012). Measuring internal audit effectiveness and efficiency. IPPF- Practice guide. Advisory Board.

Inua, O. I., \& Maduabum, C. (2014). Performance efficiency measurement in the Nigerian public sector: The Federal Universities Dilemma. Mediterranean Journal of Social Sciences, 5(20), 838.

Kaplan, R. S., \& Norton, D. P. (1996). Putting the balance score cards to work. Harvard Business Review, $134-147$.

Kiabel, B. D. (2012). Internal auditing and performance of government enterprises: a Nigerian study. Global Journal of Management and Business Research, 12(6).

Lianne, D. (2011). Inquiry into finance company failure. Report of the Commerce Committee Presented at the House of Representative, Nigeria

Mahzan, N., \& Hassan, N. A. (2015). Internal audit of quality in SS environment: perceptions on critical factors effectiveness and impact on organizational performance. International Journal of Academic Research in Accounting, Finance and Management Sciences, 5(1), 92-102

Modibo, S. A. (2015). Impact of internal audit unit on the effectiveness of internal control system of tertiary educational institution on Adamawa state, Nigeria. International Journal of Humanities of Social Science and Education 2(5), 140-156.

Norwani, N. M., Zam, Z. M., \& Chek, I. T. (2011). Corporate governance failure and its impact on financial reporting within chosen companies. International Journal of Business and Social Science, 2(21).

Obeid, O. (2010). Evaluating the effectiveness of internal audit in Sudan. Internal Audit Conference Proceedings, 15.

Okechukwu, A. U. and Kida, I. M. (2011). Effectiveness of internal audit as instrument of improving public sector management. Journal of Emerging Trends in Economics and Management Sciences, 2 (4).

Radu, M (2012). Corporate governance, internal audit and environmental audit-the performance tools in Romanian companies. Accounting and Management Information Systems, 11(1), 112. 
Richards, P. J., Devinney, T. M., Yip, G. S., \& Johnson, G. (2008). Measuring organizational performance as a dependent variable: Towards methodological best practice. Strategic Management Journal 5(2)

Sekaran, U. (2003). Research Method for Business: A Skill Building approach. $4^{\text {th }}$ edition, New Jersey, John Wiley and Sons.

Sekaran, U., \& Bougie, R. (2010). Research Method for Business. A Skills Building Approach.5th edition, UK, John Wiley and Son.

Shehu, M. (2014). Market Orientation, Knowledge Management, Entrepreneurial Orientation and Performance of Nigerian SME's. An Academic Thesis, University Utara Malaysia, 2014.

Unegbu, A. O., \& Kida, M. I. (2011). Effectiveness of internal audit as instrument of improving public Sector management. Journal of emerging trends in economics and management sciences, 2(4), 304-309.

Ussahawanitchakit, A., \& Intakhan, A. (2011). Audit professionalism, audit independence and audit effectiveness of CPAs in Thailand. International Journal of Business Research, 11(2), 1-11.

Zaire, M. (2014).The effect of audit quality on the performance of listed companies in Tehran Stock Exchange. International Letters of Social and Humanistic Sciences, (21), 3-43.

Zikmud, W. G., Babin, B. J., Carr, J. C., \& Graffin, M. (2010). Business Research Method, $8^{\text {th }}$ Edition, Canada: South Western, Cengage Learning. 